\title{
BRIDLE PLAQUES WITH ZOOMORPHIC AND ANTHROPOMORPHIC IMAGES OF THE NOMADS OF THE SOUTHERN URALS IN THE SCYTHIAN TIME ${ }^{1}$
}

\author{
Vladimir N. Myshkin \\ Samara State University of Social Sciences and Education, Samara, Russia
}

\begin{abstract}
The article is devoted to characterizing bridle plaques with zoomorphic and anthropomorphic images, which were used by the nomads of the Southern Urals in the $6^{\text {th }}-4^{\text {th }}$ centuries BC. The paper presents a summary of these horse ammunition items, which includes about 80 finds. The author proposes a typology of these subjects. Types of bridle plaques are distinguished by a combination of features that characterize the plot, composition and style of images. The items are represented by various types of plaques in the form of predatory and hoofed animals, birds, several species of animals or their parts, fish, and a rider on a horse. All the plaques are divided into four chronological groups in accordance with currently accepted dates of the monuments, where they were found: the late $6^{\text {th }}$ - the early $5^{\text {th }}$ century BC, the late $6^{\text {th }}-$ the $5^{\text {th }}$ century BC, the late $5^{\text {th }}-$ the $4^{\text {th }}$ century BC, the late $6^{\text {th }}$ - the $4^{\text {th }}$ century BC. Thus, nomads used plaques with zoomorphic images throughout the period under consideration. The distribution of types of plaques with zoomorphic images on chronological groups demonstrates both continuity in the nomads' culture development throughout the $6^{\text {th }}-4^{\text {th }}$ centuries $\mathrm{BC}$ and cultural transformations that occurred during this period. The transformations are reflected in changing nomenclature in the category of horse ammunition, style of zoomorphic images (including due to the appearance of plaques indicating links with the Don region, the North Caucasus, and the North Pontic region), and emergence of a tradition to use plaques with anthropomorphic images.
\end{abstract}

Key words: the early Iron Age, the Southern Urals, nomads, the Scythian time, horse equipment, bridle plaques.

Citation. Myshkin V.N., 2019. Bridle Plaques with Zoomorphic and Anthropomorphic Images of the Nomads of the Southern Urals in the Scythian Time. The Lower Volga Archaeological Bulletin, vol. 18, no. 1, pp. 57-73. (in Russian). DOI: https://doi.org/10.15688/nav.jvolsu.2019.1.5

\section{УЗДЕЧНЫЕ БЛЯШКИ \\ С ЗООМОРФНЫМИ И АНТРОПОМОРФНЫМИ ИЗОБРАЖЕНИЯМИ У КОЧЕВНИКОВ ЮЖНОГО ПРИУРАЛЬЯ СКИФСКОГО ВРЕМЕНИ ${ }^{1}$}

\author{
Владимир Николаевич Мышкин \\ Самарский государственный социально-педагогический университет, г. Самара, Российская Федерация
}

\footnotetext{
Аннотация. Статья посвящена характеристике уздечных бляшек с зооморфными и антропоморфными изображениями, которые использовались кочевниками Южного Приуралья в VI-IV вв. до н.э. Представлена сводка этих деталей конской амуниции, которая включает в себя около 80 находок. Предложена типология ‡े этих предметов. Типы уздечных бляшек выделены по сочетанию признаков, характеризующих сюжет, композицию и стилистику изображений. Рассматриваемые предметы представлены различными типами бляшек в виде хищных и копытных животных, птиц, нескольких видов животных или их частей, рыб, всадника на коне. Все бляшки в соответствии с принятыми в настоящее время датами памятников, в которых они обнаружены, разделены на четыре хронологические группы: конца VI - начала V в. до н.э., конца VI - V в. до н.э., конца V-IV в. до н.э., конца VI - IV в. до н.э. Таким образом, бляшки с зооморфными изображениями использовались кочевниками на протяжении всего рассматриваемого периода. Распределение типов бляшек с зооморфными изобра-
} 
жениями по хронологическим группам демонстрирует как преемственность в развитии культуры кочевников на протяжении VI-IV вв. до н.э., так и происходившие в этот период культурные трансформации. Последние нашли отражение в изменении номенклатуры рассматриваемой категории принадлежностей конского снаряжения, стилистике зооморфных изображений (в том числе за счет появления бляшек, указывающих на связи с Подоньем, Северным Кавказом, Северным Причерноморьем), возникновении традиции использования бляшек с антропоморфными изображениями.

Ключевые слова: ранний железный век, Южное Приуралье, кочевники, скифское время, снаряжение коня, уздечные бляшки.

Цитирование. Мышкин В. Н., 2019. Уздечные бляшки с зооморфными и антропоморфными изображениями у кочевников Южного Приуралья скифского времени // Нижневолжский археологический вестник. T. 18, № 1. C. 57-73. DOI: https://doi.org/10.15688/nav.jvolsu.2019.1.5

Уздечные бляшки являются наиболее массовой категорией предметов конской амуниции, происходящей из кочевнических курганов скифского времени на Южном Урале. Поэтому разработка типологии этих предметов с последующим использованием в хронологических построениях представляется весьма важным и перспективным направлением в исследовании культуры южноуральских номадов. В настоящее время эта тема продолжает оставаться актуальной, несмотря на то что отдельные ее аспекты разрабатывались на протяжении длительного времени.

К.Ф. Смирнов, рассматривая уздечные наборы Южного Приуралья VI-IV вв. до н.э., специально не останавливался на этой категории принадлежностей конской сбруи. Он лишь дал характеристику бляшкам из кург. 1 у с. Покровка, кург. 5 могильника Пятимары II, отметив их сходство между собой. Кроме того, исследователь отметил близость изображений, украшавших эти предметы и налобники из кургана у хут. Черниговского, и датировал указанные уздечные комплексы ранним V в. до н.э. [Смирнов, 1961, с. 94-95; 1964, c. 47,53$]$. Долгое время в работах, посвященных культуре кочевников Южного Приуралья в VI-IV вв. до н.э., содержалось в основном описание отдельных групп уздечных бляшек.

Среди обобщающих работ следует отметить исследования А.Д. Таирова, в которых представлено распределение этих деталей конского снаряжения из курганов Южного Зауралья на хронологической шкале [Таиров, 2000, с. 142 , рис. $41 ; 2004$, с. 3-9, рис. 6].

М.А. Очир-Горяева в своей монографии, посвященной всадникам Евразии в раннем железном веке, не затрагивая вопросов типологии, отметила различия в распределении некоторых групп уздечных блях с зооморфными изображениями на хронологической шкале. По ее наблюдениям, к особенностям ранней группы предметов конской амуниции, датируемой второй половиной VI - началом V в. до н.э., следует отнести использование круглых бляшек с профилем птицы на краю. Наборы снаряжения коня V в. до н.э., по мнению М.А. Очир-Горяевой, бляшки-украшения ремней, как правило, не содержали, хотя в некоторых встречены экземпляры с зооморфными изображениями, выполненные в пышном зверином стиле. Характерной чертой поздней группы предметов, датированных концом V - IV в. до н.э., является большое количество бляшек, выполненных в зверином стиле, отличном от стиля зооморфных изображений двух первых групп и характеризующемся большей схематичностью, прочерченностью на плоских ажурных пластинах. В то же время изображения на предметах из кург. 1 могильника Филипповка I схожи с образцами звериного стиля на предметах конской амуниции наборов $\mathrm{V}$ в. до н.э. [Очир-Горяева, 2012, с. 261, 263, 270, 271].

Типология нащечных бляшек и украшений наносного / налобного ремня, использовавшихся всадниками Сарматии, в том числе и кочевниками Южного Приуралья в VI-IV вв. до н.э., была предложена Н.Е. Берлизовым. Всю совокупность этих принадлежностей сбруи, данные о которых имелись в его распоряжении, исследователь разделил на три типа. Первый тип - это круглые уплощеннополусферические бляшки, имеющие крупные размеры и разделенные на два варианта по наличию или отсутствию изображения на щитке. Во второй тип были выделены круглые полусферические бляшки, имеющие небольшой диаметр. Зооморфные бляшки с петлей на обороте включены в тип 3 , который, в свою очередь, по характеру изображений и разме- 
ру разделен на 29 вариантов [Берлизов, 2011, c. 105-106, табл. 44Б]. Эти варианты представлены в виде таблицы с рисунками без текстового пояснения, что затрудняет точное понимание критериев их выделения.

Публикация материалов из кочевнических курганов Южного Урала [Гуцалов, 2010, c. 51-66; 2011, с. 81-96; Мамедов, Китов, 2015, с. 19-60; Моргунова, Краева, 2012, с. 156-199; Пшеничнюк, 2012; Сиротин, 2015a, с. 247-255; 2015б, с. 18-19; Федоров, Васильев, 2017, c. 54-62; Яблонский, 2013], которые не были учтены в указанных исследованиях, заставляет вновь обратиться к анализу бляшек, украшавших конскую амуницию. В данной статье рассматриваются бляшки, место которых в наборах конской амуниции в большинстве случаев не определено даже на уровне предварительной интерпретации ${ }^{2}$, что нашло отражение в их обобщенном обозначении - «уздечные бляшки». По этой причине они рассматриваются отдельно от бляшек - налобных подвесок, имитирующих клык кабана [Мышкин, 2014, с. 605-610], ряда некоторых типов бляшек, которые интерпретированы как украшения наносного или налобного ремней [Мышкин, 2015, с. 273-280], а также налобников [Мышкин, 2018a, с. 5-17].

Такие уздечные бляшки, происходящие из южноуральских курганов VI-IV в. до н.э., представляется возможным разделить на две группы. В первую можно включить экземпляры, имеющие простую геометрическую форму. В статье они не рассматриваются. Вторая группа объединяет экземпляры со щитками, которые имеют сложную конфигурацию, обусловленную сюжетом зооморфных и антропоморфных изображений.

Данная статья посвящена исследованию второй группы. В работе представлена сводка, включающая около 80 опубликованных находок. Предложены типология этих бляшек и их группировка в соответствии с хронологическими позициями, определенными по принятым в настоящее время датам погребальных комплексов, в которых они были обнаружены.

Рассматриваемая группа бляшек разделена на подгруппы в соответствии с зооморфным или антропоморфным образом: 1 - хищные животные; 2 - копытные животные; 3 птицы; 4 - рыбы; 5 - несколько животных или синкретичные образы, сочетающие черты нескольких животных; 6 - сочетание зооморфных и антропоморфных изображений.

Типы бляшек выделены по сочетанию следующих признаков.

Характеристика щитка: 1 - сплошной; 2 ажурный.

Наличие петли на внутренней стороне: 1 есть; 2 - нет.

Характеристика изображения на щитке: 1 барельеф; 2 - контррельеф; 3 - койланаглиф; 4 сквозной рельеф.

Сюжет зооморфных и/или антропоморфных изображений: 1 - фигура хищника; 2 волчья голова; 3 - волчья голова, дополненная изображением головы грифона; 4 - голова / головы горного козла, барана; 5 - голова козла, рога которого оформлены в виде головы грифона; 6- голова / головы атилопы; 7 - фигура оленя, козла, барана; 8 - фигура бараногрифона; 9 - голова / головы хищной птицы / грифона; 10 - рыба; 11 - голова грифона в сочетании с фигурой кошачьего хищника; 12 - фигура верблюда; 13 - голова верблюда; 14 - фантастическое животное, сочетающее черты верблюда и хищной птицы; 15 - всадник на коне.

Проекция изображений на щитках: 1 прямая проекция; 2 - боковая проекция (изображение в профиль); 3 - сочетание прямой и боковой проекции.

Характеристика однофигурной композиции при изображении животного: 1 - припавшее к земле животное; 2 - стоящее животное; 3 - свернувшееся кольцом животное; 4 бегущее животное.

Группа 2. Бляшки, имеющие сложную конфигурацию, которая обусловлена сюжетом и композицией зооморфных и/или антропоморфных изображений

\section{1. Бляшки, щитки которых оформлены в виде фигуры или части хищуного животного}

Тип 2.1.1. Бляшки в виде фигуры припавшего к земле хищника, изображенного в профиль (рис. 1,1-5). Голова животного при этом опущена вниз, передние лапы подогнуты. На обратной стороне имеется петля для проде- 
вания ремня. В выборке этот тип представлен 5 экземплярами. Обнаружены: Аландский III, кург. 5 - 1 экз. (рис. 1,1), комплекс датирован концом VI - началом V в. до н.э. [Мошкова, 1972, с. 62, 68, рис. 4,1]; Кырык-Оба II, кург. 12, пола - 1 экз. (рис. 1,2), комплекс датирован концом VI - первой половиной V в. до н.э. [Гуцалов, 2011, с. 84, 93, рис. 2,5]; Переволочан II, кург. $4-3$ экз. (рис. 1,3-5) [Сиротин, 2015a, с. 247, 253, рис. 1,5].

Тип 2.1.2. Бляшка в виде изображенного в профиль хищника с повернутой назад головой, стоящего на прямых лапах. На внутренней стороне имеется петля. Обнаружена: Сапибулак, кург. 6, погр. 4 - 1 экз. (рис. 1,6), комплекс датирован концом VI - V в. до н.э. [Mамедов, Китов, 2015, с. 38, 52, рис. 11,2].

Тип 2.1.3. Крупные металлические бляшки (рис. $1,11,12$ ) в виде профильного изображения головы волка с оскаленной пастью. Щиток бляшек сплошной: пасть волка оскалена, но челюсти изображены сомкнутыми, при передаче уха и носа использованы завитки, миндалевидный глаз передан схематично, отсутствуют какие-либо дополнительные элементы, усложняющие композицию, поверхность щитка в целом гладкая. Автор публикации полагает, что изображение синкретичное, сочетающее черты волка и хищной птицы (по всей видимости, имеются в виду очертания бляшки с внутренней стороны). На обратной стороне бляшек находится петля для продевания ремня. В рассматриваемой выборке этот тип представлен шестью экземплярами. Обнаружены: Кырык-Оба II, кург. 18 - 6 экз. (рис. $1,11,12$ ), комплекс датирован временем в пределах конца VI- первой половины V в. до н.э. [Гуцалов, 2010, с. 58,64 , рис. $6,12,13$ ].

Тип 2.1.4. Металлические бляшки в виде длинномордой головы волка с оскаленной пастью, изображенной в профиль. Щитки бляшек не сплошные. По деталям изображения представляется возможным выделить два варианта. Вариант 1 представлен бляшками «с параллельными или чуть расходящимися челюстями, длинным подтреугольным горизонтальным ухом, прижатым к шее и с дополнительной деталью на подбородке (это акцентирование скулы с помощью выступа либо превращение этого выступа в глаз птицы, клюв, которой уходит вверх по дуге, окайм- ляя голову хищника.., либо, наконец, дополнительный глаз хищника, превращающий данный профиль одновременно в соединение двух профилей, формирующих единый фас хищника)» [Канторович, Яблонский, 2009, с. 70]. Под ухом, на задней части головы и щеке размещено изображение повернутой клювом вверх головы грифона или трех окружностей. На внутренней стороне имеется петля для продевания ремня. Этот вариант представлен 3 экземплярами (рис. 1,8-10). Обнаружены: Филипповка I, кург. 3 - 1 экз. (рис. 1,8) [Пшеничнюк, 2012, с. 32, рис. 57,12], кург. 4, жертвенный комплекс $1-1$ экз. (рис. 1,9); кург. 15, погр. 3 - 1 экз. (рис. 1,10) [Яблонский, 2013, c. 66 . № 33, с. 174, № 2141]. Комплексы датированы началом IV в. до н.э. [Пшеничнюк, 2012 , с. 87], второй половиной V - IV в. до н.э. [Яблонский, 2008a, с. 262; 2008б, с. 173; Канторович, Яблонский, 2009, с. 82-83], концом $\mathrm{V}$ - третьей четвертью IV в. до н.э. [Трейстер, Яблонский, 2012, с. 282-284].

Вариант 2 представлен бляшкой (рис. 1,7), на которой изображение волчьей головы отличается от изображений на бляшках варианта 1 рядом деталей: голова не столь длинномордая, в раскрытой пасти выделены только клыки, заходящие друг за друга, жевательные зубы не показаны, ухо приподнято. Обнаружена: Филипповка I, кург. 21, околокурганное пространство - 1 экз. (рис. 1,7), комплекс датирован временем в пределах второй половины V-IV в. дон.э. [Яблонский, 2013, № 2154; 2008a, c. $262 ; 20086$, с. 173 ; Канторович, Яблонский, 2009 , с. 82, 83], конца V - третьей четверти IV в. до н.э. [Трейстер, Яблонский, 2012, с. 282-284], IV в. до н.э. [Мышкин, 2018б, с. 285].

Тип 2.1.5. Металлическая бляшка в виде головы хищного животного (волка?), изображенной анфас (рис. 1,13). Близкие в стилистическом отношении изображения представлены на бляшках из погр. 1 у с. Хошеутово в Астраханской области на левобережье Волги [Очир-Горяева, 2012, с. 210, илл. 233,94,95], датированного первой половиной (возможно, второй четвертью) V в. до н.э. [Дворниченко, Очир-Горяева, 1997, с. 111-113]. Нашивные бляшки со схожим изображением найдены в кург. 2 могильника у с. Покровка (раскопки 1911 г.), датированном началом V в. до н.э. [Смирнов, 1964, рис. $16,2 \kappa-л$, с. 47]. С.В. Си- 
ротин, автор раскопок, опубликовавший данную находку, полагает, что на ней изображены сдвоенные головы горных козлов [Сиротин, $2015 \mathrm{a}$, с. 253]. На обратной стороне бляшки имеется петля. Найдена: Переволочан II, кург. 4-1 экз. (рис. 1,13) [Сиротин, 2015а, с. 247, 253 , рис. 1,4$]$.

\section{2. Бляшки, щуитки которых}

оформлены в виде фигуры

или части копытного животного

Тип 2.2.1. Металлические бляшки в виде изображения в профиль двух голов горных козлов с общим ухом. На внутренней стороне бляшек имеется петля (рис. 2,1-3). Этот тип в анализируемой выборке представлен 5 экземплярами. Найдены: Обручевский, кург. 2 3 экз. (рис. 2,1), комплекс датирован концом VI - началом V в. до н.э. [Гаврилюк, Таиров, 1993 , с. 53,65 , рис. 5,3$]$; курган у озера Кайранкуль в Кустанайской области (раскопки С.И. Руденко 1921 г.) - 2 экз. (рис. 2,2,3) [Грязнов, 1956, с. 15 , рис. $4,2,3]$.

Тип 2.2.2. Металлические и костяные бляшки в виде изображения головы горного козла или барана в профиль (рис. 2,4-7). Этот тип в анализируемой выборке представлен 5 экземплярами. Найдены: Аландский III, кург. 5 - 1 экз. (рис. 2,4), комплекс датирован концом VI - началом V в. до н.э. [Мошкова, 1972, с. 62, рис. 4,2]; Филипповка I, кург. 4, жертвенный комплекс $1-1$ экз. (рис. 2,5) и кург. 15, погр. 1 и 3 - 3 экз. (рис. 2,6,7), комплексы датированы временем в пределах второй половины (конца) V - IV в. до н.э. [Яблонский, 2013 , с. $65,142,143,174$, № 27,1684 , 1685,$2142 ; 2008$ a, c. $262 ; 20086$, с. 173 ; Канторович, Яблонский, 2009 , с. 82,83$]$, конца V третьей четверти IV в. до н.э. [Трейстер, Яблонский, 2012, с. 282-284].

Тип 2.2.3. Металлические и костяные бляшки, представляющие собой профильное изображение головы горного козла, рога которого оформлены в виде головы грифона (рис. 2 , 8-11). Найдены: Филипповка I, кург. 3 - 1 экз. (рис. 2,8), комплекс датирован началом IV в. до н.э. [Пшеничнюк, 2012 , с. 32,87 , рис. 57,8 ], серединой - второй половиной IV в. до н.э. [Канторович, Яблонский, 2009, с. 82, 83], концом V - третьей четвертью IV в. до н.э. [Трей- стер, Яблонский, 2012, с. 282-284]; кург. 4, жертвенный комплекс $1-3$ экз. (рис. 2,9-11), комплекс датирован временем в пределах второй половины (конца) V - IV в. до н.э. [Яблонский, 2013, с. 66, 67, 75, № 32, 39, 81; Канторович, Яблонский, 2009, с. 82, 83], конца $\mathrm{V}$ - третьей четверти IV в. до н.э. [Трейстер, Яблонский, 2012, c. 282-284].

Тип 2.2.4. Металлическая бляшка в виде двух голов антилоп в профиль, обращенных мордами в противоположные стороны, а рогами - друг к другу, на внутренней стороне имеется петля для продевания ремня. Найдена: Бесоба, кург. 5 - 1 экз. (рис. 2,12), комплекс датирован концом VI - V в. до н.э. [Кузнецова, Курманкулов, 1993, с. 48, рис. 3,1; Кадырбаев, 1984, с. 91].

Тип 2.2.5. Металлические и костяные бляшки в виде фигуры лежащего оленя (изображение в профиль, также может быть интерпретировано как фигура козла или барана), у которого показаны только две согнутые и направленные вперед ноги, а голова с удлиненной мордой опущена вниз почти перпендикулярно к телу (рис. 2,13-15). Найдены: Филипповка I, кург. 4, жертвенный комплекс 1 - 2 экз. (рис. $2,14,15$ ), кург. 21, прилегающая территория - 1 экз. (рис. 2,13), датированы в пределах второй половины (конца) V - IV в. до н.э. [Яблонский, 2013, с. 77, 177, № 90, 91, 2155; $2008 \mathrm{a}$, c. $262 ; 20086$, с. 173 ; Канторович, Яблонский, 2009, с. 82, 83], конца V - третьей четверти IV в. до н.э. [Трейстер, Яблонский, 2012, c. 282-284].

Тип 2.2.6. Бляшки (рис. 2,16-19) в виде фигуры свернувшегося кольцом животного «со стилизованными чертами бараногрифона» [Сиротин, 2015a, с. 247], с петлей для продевания ремня на внутренней стороне. В анализируемой выборке этот тип представлен 4 экземплярами. Обнаружены: Переволочан II, кург. 4 - 4 экз. [Сиротин, 2015а, с. 247, 253, рис. 1,6].

\section{3. Бляшки, оформленные \\ в виде фигуры птиць или какой-то ее части}

Тип 2.3.1. Металлические бляшки в виде головы хищной птицы / грифона, изображенной в профиль (рис. 3,1-3). Бляшки этого типа 
разделены на 2 варианта. Вариант 1 - бляшки с вполне реалистичным изображением головы хищной птицы / грифона. Обнаружены: Обручевский, кург. 2 - 1 экз. (рис. 3,1 ), комплекс датирован концом VI - началом V в. до н.э. [Гаврилюк, Таиров, 1993, с. 59, 65, рис. 5,4]; Большой Климовский курган - 1 экз. (рис. 3,2 ), комплекс датирован концом VI - началом V в. до н.э. [Таиров, 2000, рис. 43, 2; 2004, с. 3, 7, 9 , рис. 10,22], концом V - IV в. до н.э. [ОчирГоряева, 2012, с. 260, 271]; Ивановские I курганы, кург. 7 - 1 экз., комплекс датирован концом V - IV в. до н.э. [Сиротин, 2015б, с. 18, $19]$. Вариант 2 - бляшка, имеющая щиток, украшенный рельефным, весьма схематичным изображением, которое можно интерпретировать как голову хищной птицы с гипертрофированными частями - круглой головой и спирально изогнутым клювом с выделенной восковицей (рис. 3,3). Обнаружена в поле кург. 10 могильника Переволочан I [Пшеничнюк, 1995, рис. 11,5], датированного второй половиной IV в. до н.э. [Сиротин, 2016, с. 259].

Тип 2.3.2. Металлические бляшки в виде двух голов хищных птиц / грифонов, изображенных в профиль, обращенных клювами в противоположные стороны, а нижней частью друг к другу (рис. 3,4-6). Одна птичья голова начинается от кончика клюва другой. На обратной стороне бляшки имеется петля для продевания ремня. Найдены: Сапибулак, кург. 6, погр. 4 - 2 экз. (рис. 3,4,6), комплекс датирован концом VI - V в. до н.э. [Мамедов, Китов, 2015, с. 38, 52, pис. 11,3,4]; Переволочан I, кург. 10, пола - 1 экз. (рис. 3,5), комплекс датирован второй половиной IV в. до н.э. [Пшеничнюк, 1995, с. 81, рис. 11,3; Сиротин, 2016, c. 259].

Тип 2.3.3. Металлические бляшки (рис. 3,7) в виде двух голов хищных птиц в профиль, обращенных клювами в противоположные стороны, при этом одна птичья голова начинается от верхней части клюва другой. Клюв верхней птичьей головы соединяется с верхней частью нижерасположенной птичьей головы. На обратной стороне бляшки имеется петля для продевания ремня. Бляшка этого типа (рис. 3,7 ) найдена в погребении кург. 17 могильника Лебедевка VII, дата которого приходится на конец VI - V в. до н.э. [Железчиков и др., 2006, с. 34,37 , рис. 74,9$]$.
Тип 2.3.4. Металлические бляшки в виде двух голов хищных птиц в профиль, обращенных клювами в противоположные стороны и имеющих одну шею. Клюв одной птичьей головы соединяется со второй птичьей головой. На обратной стороне бляшки имеется петля для продевания ремня. Бляшка этого типа (рис. 3,8 ) найдена в кург. 12 могильника Филипповка I [Пшеничнюк, 2012. с. 51, рис. 118,10]. Комплекс датирован началом IV в. до н.э. [Пшеничнюк, 2012, с. 87], второй половиной V IV в. до н.э. [Яблонский, 2008a, с. 262; 2008б, c. 173], концом V - третьей четвертью IV в. до н.э. [Трейстер, Яблонский, 2012, с. 282-284].

Тип 2.3.5. Бляшка, которая своей общей конфигурацией напоминает контуры головы длинноклювой птицы. В верхней, более широкой части щитка один над другим располагаются изображения голов двух ушастых грифонов в профиль. Головы повернуты в одну сторону. Сужающееся и заостренное окончание бляшки может быть трактовано как опущенное вниз расправленное крыло. В то же время эту часть бляшки можно трактовать как длинный клюв птицы, а мелкие рельефные головки грифонов - как глаз и ухо более крупного изображения (рис. 3,9 ). Бляшка этого типа обнаружена в 100 м к юго-западу от кург. 1 могильника Филипповка I [Яблонский, 2013 , с. 222, № 3126]. Комплекс датирован началом IV в. до н.э. [Пшеничнюк, 2012, с. 87], второй половиной V - IV в. до н.э. [Яблонский, 2008a, с. 262; 2008б, с. 173], концом Vтретьей четвертью IV в. до н.э. [Трейстер, Яблонский, 2012, с. 282-284].

Тип 2.3.6. Металлическая бляшка, конфигурация которой напоминает расправленное птичье крыло, один ее более широкий конец закругляется, второй плавно заостряется, края волнистые (рис. 3,10). Обнаружена: Филипповка I, кург. 1, околокурганноепространство-1 экз. (рис. 3,10) [Яблонский, 2013, с. 223, № 3127], комплекс датирован началом IV в. до н.э. [Пшеничнюк, 2012, с. 87], второй половиной V - IV в. до н.э. [Яблонский, 2008а, с. 262; 2008б, с. 173], концом V - третьей четвертью IV в. до н.э. [Трейстер, Яблонский, 2012, с. 282-284].

Тип 2.3.7. Металлические бляшки в виде птичьей головы во фронтальной проекции (рис. 3,11,12). Обнаружены: Кырык-Оба II, кург. 16 - 2 экз. (рис. 3,11,12), комплекс да- 
тирован концом VI - первой половиной V в. до н.э. [Гуцалов, 2011, с. 87, 93, рис. 5,3,4].

Тип 2.3.8. Металлические бляшки в виде округлого плоского щитка, верхний край которого имеет выступ, расположенный в той же плоскости и оформленный в виде головы хищной птицы. Изображение рельефное, голова изображена в профиль (рис. 3,13-21). Обнаружены: Пятимары II, кург. 5 - 10 экз. (рис. 3, 13-21); Покровка, кург. 1 (раскопки 1911 г.) 2 экз., комплексы датированы началом $\mathrm{V}$ в. до н.э. [Смирнов, 1961 , с. 94 , рис. $54 ; 1964$, с. 47 , 53 , рис. 34,16 ; Очир-Горяева, 2012, с. 260, 271].

\section{4. Блямки в виде рыбы}

Тип 2.4.1. Бляшки в виде рыбы, характеризующиеся реалистичным рельефным изображением. На обороте каждой бляшки имеется петля для продевания ремня (рис. 4,1-3). Обнаружены: Нагорненский, кург. 6, погр. 1 (рис. 4,1), кург. 9, погр. 8 (рис. 4,2); Кызыл-Жар, кург. 1 3; Уркач I, кург. 23 (рис. 4,3); Ивановские I курганы, кург. $7^{4}$ [Королькова, 2006 , с. 235 , табл. 1,3,6, 7; Федоров, 2015, c. 256; Сиротин, 2015б, с. 19]. Первые четыре комплекса датированы концом VI - V в. до н.э. [Королькова, 2006, с. 235; Федоров, 2015, c. 259], кург. 7 Ивановских I курганов - концом V - IV в. до н.э. [Сиротин, 2015б, с. 19].

Тип 2.4.2. Плоские бляшки в виде рыбы, некоторые из них представляют собой достаточно реалистичные изображения, некоторые - весьма схематичные (рис. 4,411). К бляшкам этого типа отнесены 9 экземпляров. Обнаружены: курган у хут. Веселый, с. Ак-Булак, - 3 экз. (рис. 4,4,5), комплекс датирован началом IV в. до н.э. [Смирнов, 1964, рис. 38,12 , с. 58; Федоров, 2015, с. 256, 257]; Акоба II, кург. 1, погр. 2 2 экз. (рис. 4,8,9), комплекс датирован второй половиной V - IV в. до н.э. [Моргунова, Краева, 2012, рис. 17,5,6, с. 175, 197]; Переволочан I, кург. 11, погр. 1 - 2 экз. (рис. 4,6, 7), комплекс датирован IV в. до н.э., второй половиной IV в. до н.э. [Сиротин, 2010, с. 327, 337, рис. 3,14; 2016, с. 260]; Сара, кург. 4, погр. 1 - 2 экз. (рис. 4,10,11), комплекс датирован второй половиной $\mathrm{V}-\mathrm{IV}$ в. до н.э. [Федоров, 2015, с. 257, 258; Федоров, Васильев, 2017, c. 59].

\section{5. Бляшки, украшенные изображениями}

со сложной композицией из двух

и более животных (или частей их тел)

Тип 2.5.1. Бляшка, верхняя часть которой оформлена в виде головы ушастого грифона, изображенного в профиль, а нижняя имеет округлую форму и украшена стилизованным изображением лежащего кошачьего хищника, представленного во фронтальной проекции (рис. 4,12). Обнаружена: Филипповка I, кург. 1, околокурганное пространство - 1 экз. (рис. 4,12) [Яблонский, 2013, с. 222, № 3125], комплекс датирован началом IV в. до н.э. [Пшеничнюк, 2012, с. 87], второй половиной V - IV в. до н.э. [Яблонский, 2008a, с. 262; 2008б, с. 173], концом V - первой половиной IV в. до н.э. [Трейстер и др., 2012, с. 85].

Тип 2.5.2. Бляшка, украшенная сильно стилизованным изображением, которое может быть интерпретировано как голова и шея какого-то существа, сочетающего черты птицы и, возможно, верблюда (рис. 4,13). Обнаружена: Филипповка I, кург. 3 - 1 экз. (рис. 4,13 ), комплекс датирован началом IV в. до н.э. [Пшеничнюк, 2012 , рис. 57,15 , с. 32,87 ], второй половиной (концом) V - IV в. до н.э. [Яблонский, 2008a, с. 262; 2008б, с. 173; Канторович, Яблонский, 2009, с. 82, 83], концом $\mathrm{V}$ - третьей четвертью IV в. до н.э. [Трейстер, Яблонский, 2012, с. 282-284].

\section{6. Бляики, имеютие}

сложную конфигуращию, которая обусловлена сочетанием антропоморфных u зооморфных изображений

Тип 2.6.1. Плоские металлические бляшки, оформленные как контурное схематичное изображение всадника на коне в профиль. Обнаружены: Переволочан I, кург. 10 (рис. 4,14) - по одним данным 3 экз. [Пшеничнюк, 1995 , с. 81 , рис. 11,13$]$, по другим 4 экз. [Очир-Горяева, 2012, с. 289, илл. 316,1]. Комплекс датирован концом V - IV в. до н.э. [Очир-Горяева, 2012, с. 260, 271], второй половиной IV в. до н.э. [Сиротин, 2016, с. 259].

Принятые в настоящее время даты погребальных комплексов, содержавших бляшки конского снаряжения, позволяют разделить эти предметы на четыре хронологических группы. 
Первая группа. В нее включены экземпляры, которые, судя по предложенным в настоящее время датам памятников, использовались в период, приходящийся на конец VI начало V в. до н.э. Это бляшки в виде фигуры припавшего к земле хищника (рис. $1,1-5$ ), изображенного в профиль (тип 2.1.1); в виде головы волка (рис. $1,11,12$ ) с оскаленной пастью, изображенной в профиль на сплошном щитке (тип 2.1.3); двух голов горных козлов (рис. 2,1-3) с общим ухом, изображенных в профиль (тип 2.2.1); в виде птичьей головы (рис. $3,11,12$ ), изображенной во фронтальной проекции (тип 2.3.7); округлые плоские (рис. 3, 13-21), верхний край которых имеет выступ, оформленный в виде головы хищной птицы (тип 2.3.8). К этой же группе следует отнести, видимо, бляшки (рис. 2,16-19) в виде фигуры свернувшегося кольцом животного «со стилизованными чертами бараногрифона» (тип 2.2.6) и бляшку (рис. 1,13) в виде головы хищного животного (волка?), изображенной анфас (тип 2.1.5).

Вторая группа объединяет бляшки, происходящие из комплексов, датированных более широко, чем памятники с бляшками первой группы, - концом VI - V в. до н.э. Это бляшки (рис. 1,6) в виде изображенной в профильной проекции фигуры стоящего хищника, с повернутой головой (тип 2.1.2); в виде двух голов антилоп, изображенных в профиль (рис. 2,12), обращенных мордами в противоположные стороны, а рогами - друг к другу (тип 2.2.4); в виде двух голов хищных птиц в профиль (рис. 3,7), обращенных клювами в противоположные стороны, при этом одна голова начинается от верхней части клюва другой (тип 2.3.3).

Третья группа объединяет детали конского снаряжения, найденные в памятниках, для которых предложена дата, приходящаяся на конец V - IV в. до н.э. Это металлические ажурные бляшки (рис. 1,7-10) со стилизованным изображением головы волка с оскаленной пастью в профиль, дополненной изображением головы грифона или ее имитацией (тип 2.1.4); металлические и костяные бляшки (рис. 2,8-11) в виде профильного изображения головы козла, рога которого трансформированы в голову грифона (тип 2.2.3); металлические и костяные бляшки (рис. 2,13-15) в виде фигуры лежащего оленя (тип 2.2.5); металлические бляшки (рис. 3,8 ) в виде двух голов хищных птиц, изображенных в профиль, обращенных клювами в противоположные стороны и имеющих одну шею (тип. 2.3.4); металлическая бляшка (рис. 3,9), общая конфигурация которой напоминает контуры головы длинноклювой птицы, в верхней части которой располагаются изображения голов двух ушастых грифонов в профиль (тип. 2.3.5); металлическая бляшка (рис. 3,10 ), конфигурация которой напоминает расправленное птичье крыло (тип. 2.3.6); бляшка (рис. 4,12), верхняя часть которой представляет собой голову ушастого грифона, изображенную в профиль, а нижняя - округлой формы, украшена стилизованным изображением лежащего кошачьего хищника, изображенного во фронтальной проекции (тип 2.5.1) и бляшка типа 2.5.2 (рис. 4,13); бляшки (рис. 4,14) в виде схематичного изображения всадника на коне (тип 2.6.1).

В четвертую группу включены бляшки, найденные как в памятниках, датированных концом VI - V в. до н.э., так и в комплексах конца V - IV в. до н.э.: металлические или костяные в виде головы горного козла или барана (рис. 2,4-7), изображенной в профиль (тип 2.2.2); в виде головы хищной птицы / грифона (рис. 3,1-3), изображенной в профиль (тип. 2.3.1); в виде двух голов хищных птиц / грифонов (рис. 3,4-б), изображенных в профиль и обращенных клювами в противоположные стороны, а нижней частью - друг к другу (тип. 2.3.2); в виде рыбы типов 2.4.1-2.4.2 (рис. 4,1-11).

Распределение рассматриваемой категории находок по хронологическим группам показывает, что уздечные бляшки с зооморфными изображениями представлены в погребальных комплексах, относимых к разным отрезкам времени в пределах VI - IV вв. до н.э. Некоторые типы бляшек, в частности, объединенные в четвертую группу, использовались на протяжении всего указанного времени. Следует отметить, что ряд образов (изображение рыбы, головы хищной птицы / грифона, оскаленной волчьей морды, головы горного козла или барана) также встречается на рассматриваемых деталях конской амуниции с конца VI - IV в. до н.э. Это свидетельствует об определенной преемственности в разви- 
тии культуры кочевников на протяжении всего рассматриваемого периода.

Вместе с тем прекращение использования в течение V в. до н.э. уздечных бляшек первой и второй групп говорит о трансформации культурных стереотипов у кочевнических сообществ Южного Приуралья. Об этом же свидетельствует фиксируемое для конца V - IV в. до н.э. изменение стилистики изображений на рассматриваемых деталях конского снаряжения. В этот период, в частности, стали использоваться бляшки в виде головы волка типа 2.1.4, демонстрирующие связи южноуральских номадов с Подоньем, Северным Кавказом, Северным Причерноморьем. При этом образцы звериного стиля на бляшках конца V - IV в. до н.э. демонстрируют тенденцию к упрощению и схематизации изображений [Кантарович, Яблонский, 2009, с. 79; Мышкин, 2018б, c. 283-285]. Следует также отметить, что погребальные памятники этого периода, содержавшие бляшки с изображениями в зверином стиле, представлены преимущественно курганами социальной элиты могильника Филиппов- ка I. Отличительной особенностью периода, приходящегося на конец V - IV в. до н.э., является также использование уздечных блях, украшенных изображениями всадника.

\section{ПРИМЕЧАНИЯ}

${ }^{1}$ Работа выполнена при поддержке Российского научного фонда, проект № 18-18-00137 «Контакты и взаимосвязи населения Урало-Поволжских и Казахстанских степей в период поздней бронзы и раннего железа».

The work was supported by Russian Science Foundation, project no. 18-18-00137 "Contacts and Interrelations of the Ural-Volga and Kazakhstan Steppe Population in the Late Bronze and Early Iron Periods".

${ }^{2}$ В совокупности находок, использовавшихся при подготовке статьи, исключение составляют, вероятно, округлые бляшки с головой грифона из кургана 1 раскопанного у с. Покровка в 1911 г и кургана 5 могильника Пятимары II. Они интерпретированы М.А. Очир-Горяевой как украшения наносного и нащечного ремней [Очир-Горяева, 2012, c. 279,310 , илл. 305,346$]$.

${ }^{3}$ Находка не опубликована.

${ }^{4}$ Находка не опубликована. 


\section{ИЛЛЮСТРАЦИИ}
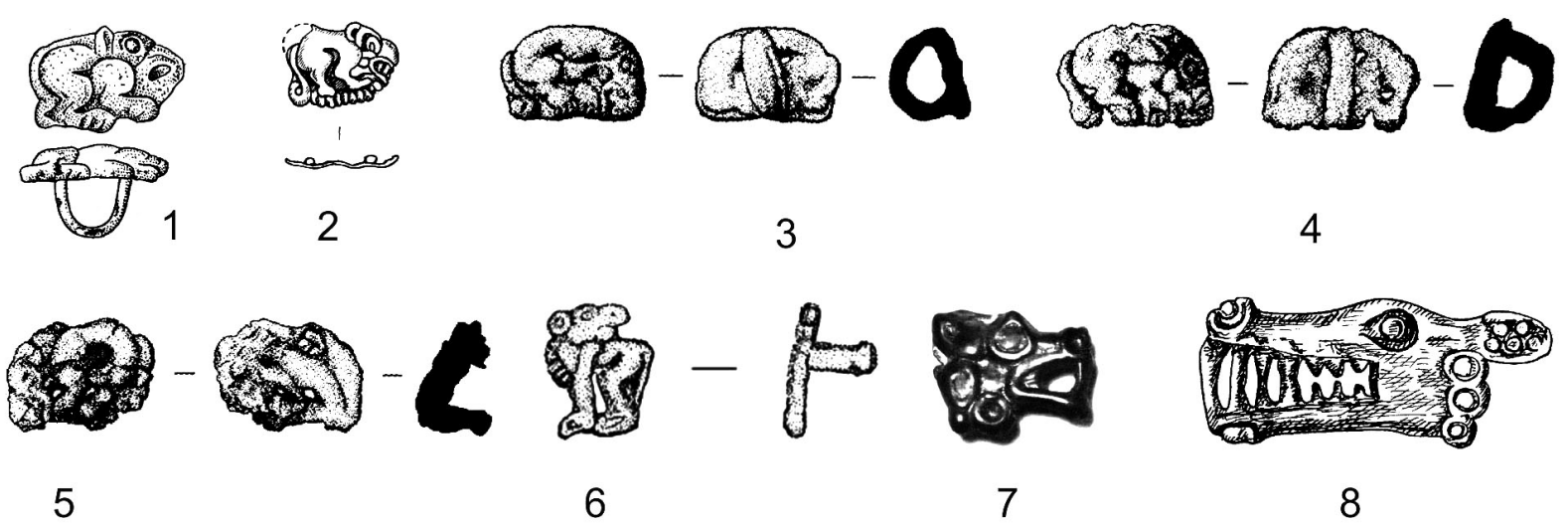

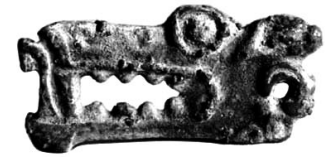

9

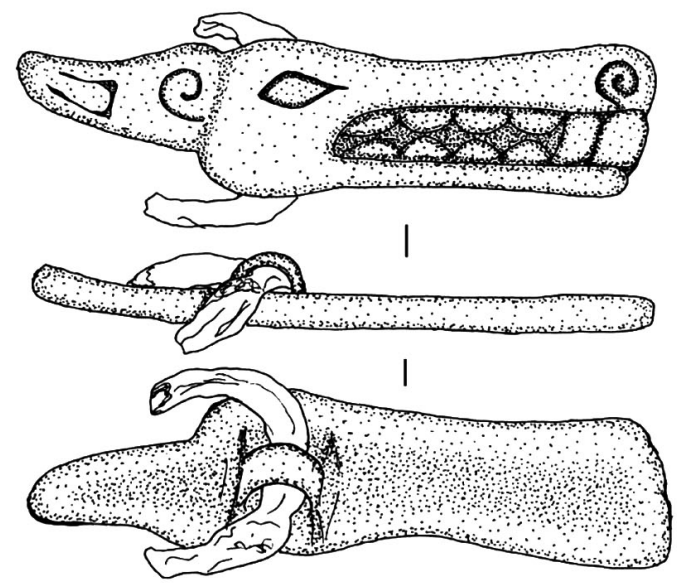

12

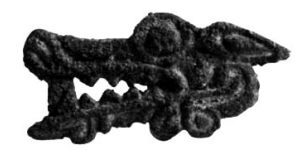

10
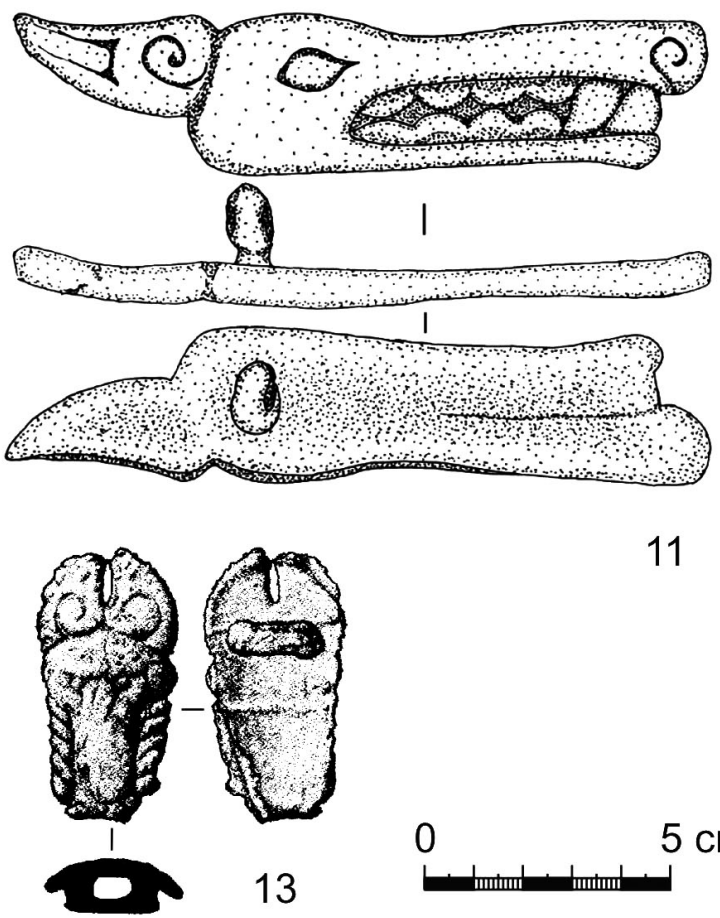

Рис. 1. Уздечные бляшки:

1 - Аландский III, кург. 5 [Мошкова, 1972, рис. 4,1]; 2 - Кырык-Оба II, кург. 12 [Гуцалов, 2011, рис. 2,5]; 3-5, 13 - Переволочан II, кург. 4 [Сиротин, 2015а, рис. 1,4,5]; 6 - Сапибулак, кург. 6, погр. 4 [Мамедов, Китов, 2015, рис. 11];

7 - Филипповка I, кург. 21 [Яблонский, 2013, № 2154]; 8 - Филипповка I, кург. 3 [Пшеничнюк, 2012, рис. 57,12];

9 - Филипповка I, кург. 4, жертвенный комплекс 1 [Яблонский, 2013, № 33]; 10 - Филипповка I, кург. 15, погр. 3 [Яблонский, 2013, № 2141]; 11-12 - Кырык-Оба II, кург. 18 [Гуцалов, 2010, рис. 6,12,13] (1, 3-13 - бронза; 2 - золото)

Fig. 1. Bridle plaques:

1 - Alandskiy III, barrow 5 [Moshkova, 1972, fig. 4,1]; 2 - Kyryk-Oba II, barrow 12 [Gutsalov, 2011, fig. 2,5]; 3-5, 13 - Perevolochan II, barrow 4 [Sirotin, 2015a, fig. 1,4,5]; 6 - Sapibulak, barrow 6, burial 4 [Mamedov, Kitov, 2015, fig. 11]; 7 - Filippovka I, barrow 21[Yablonsky, 2013, no. 2154]; 8 - Filippovka I, barrow 3 [Pshenichnyuk, 2012, fig. 57,12]; 9 - Filippovka I, barrow 4, sacrificial complex 1 [Yablonsky, 2013, no. 33]; 10 - Filippovka I, barrow 15, burial 3 [Yablonsky, 2013, no. 2141]; 11-12 - Kyryk-Oba II, barrow 18 [Gutsalov, 2010, fig. 6,12,13] (1,3-13 - bronze; 2 - gold) 


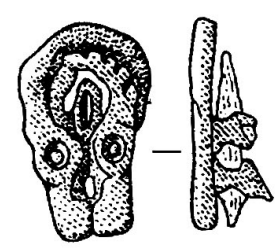

1

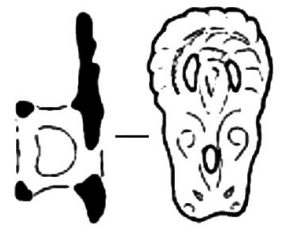

2

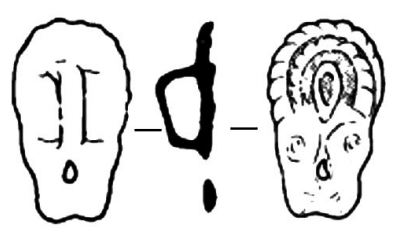

3

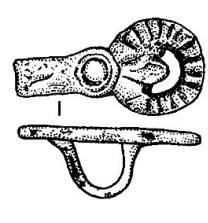

4

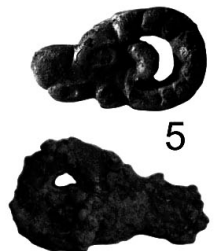

6

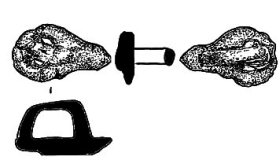

7

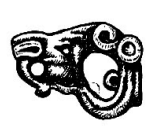

8

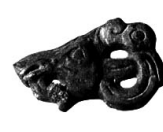

9

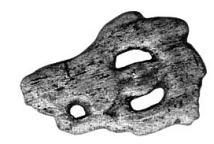

10

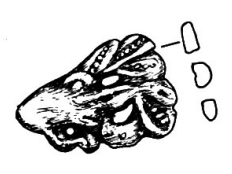

11

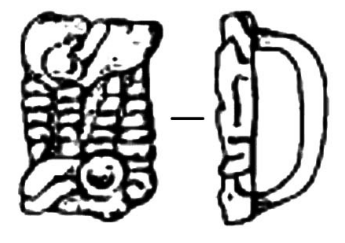

12

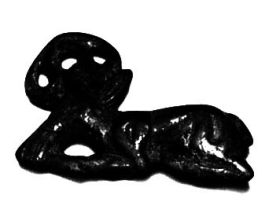

13

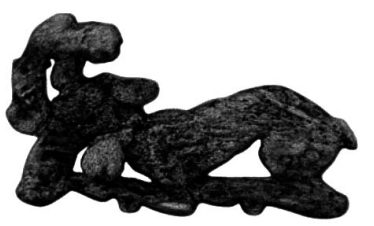

14

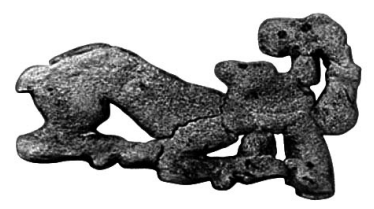

15

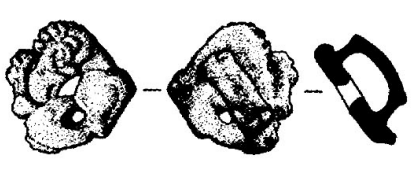

16

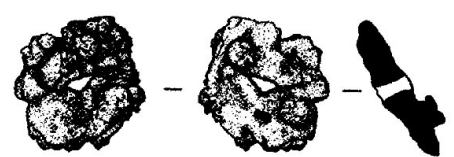

17

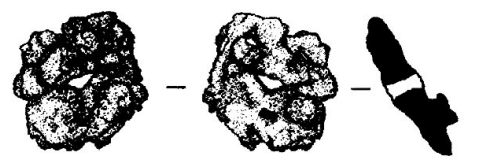

18

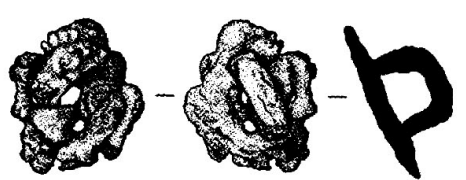

19

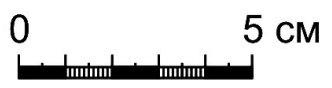

Рис. 2. Уздечные бляшки:

1 - Обручевский, кург. 2 [Гаврилюк, Таиров, 1993, рис. 5,3]; 2-3 - кург. у о. Кайранкуль [Грязнов, 1956, рис. 4,2,3]; 4 - Аландский III, кург. 5 [Мошкова, 1972, рис. 4,2]; 5, 9-11, 14-15 - Филипповка I кург. 4, жертвенный комплекс 1 [Яблонский, 2013, № 27, 32, 39, 81, 90, 91]; 6-7 - Филипповка I кург. 15, погр. 1, 3

[Яблонский, 2013, № 1685, 2142]; 8 - Филипповка I, кург. 3 [Пшеничнюк, 2012, рис. 57,8]; 12 - Бесоба, кург. 5 [Кузнецова, Курманкулов, 1993, рис. 3,1]; 13 - Филипповка I, кург. 21 [Яблонский, 2013, № 2155];

16-19 - Переволочан II, кург. 4 [Сиротин, 2015а, рис. 1,6] (1-9, 12-13, 16-19- бронза; 10-11, 14-15 - кость)

Примечание. Масштаб указан для 1-4, 6-8, 10-11, 13-19.

Fig. 2. Bridle plaques:

1 - Obruchevskiy, barrow 2 [Gavrilyuk, Tairov, 1993, fig. 5,3]; 2-3 - barrow near lake Kayrankul [Gryaznov, 1956, fig. 4,2,3]; 4 - Alandskiy III, barrow 5 [Moshkova, 1972, fig. 4,2]; 5, 9-11, 14-15 - Filippovka I, barrow 4, sacrificial complex 1 [Yablonsky, 2013, no. 27, 32, 39, 81, 90, 91]; 6-7 - Filippovka I, barrow 15, burials 1, 3

[Yablonsky, 2013, no. 1685, 2142]; 8 - Filippovka I, barrow 3 [Pshenichnyuk, 2012, fig. 57,8]; 12 - Besoba, barrow 5

[Kuznetsova, Kurmankulov, 1993, fig. 3,1]; 13 - Filippovka I, barrow 21 [Yablonsky, 2013, no. 2155];

16-19 - Perevolochan II, barrow 4 [Sirotin, 2015a, fig. 1,6] (1-9, 12-13, 16-19- bronze; 10-11, 14-15 - bone)

Note. The size is specified for $1-4,6-8,10-11,13-19$. 


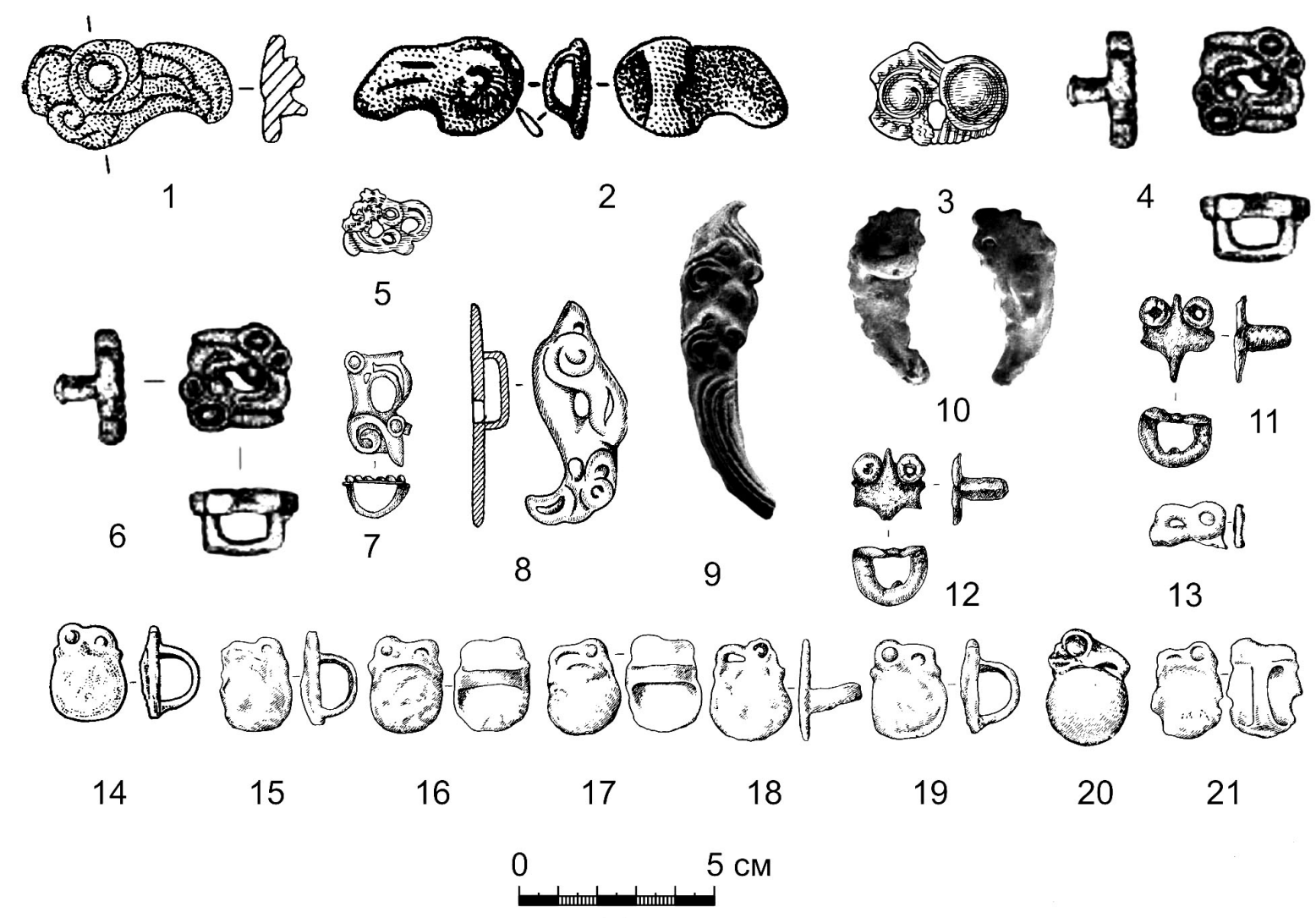

Рис. 3. Бронзовые уздечные бляшки:

1 - Обручевский, кург. 2 [Гаврилюк, Таиров, 1993, рис. 5,4]; 2 - Большой Климовский [Таиров, 2000, рис. 43,2];

3, 5 - Переволочан I, кург. 10 [Пшеничнюк, 1995, рис. 11,3; Мамедов, Китов, 2015, рис. 11,4]; 4, 6 - Сапибулак, кург. 6, погр. 4 [Мамедов, Китов, 2015, рис. 11,3; Пшеничнюк, 1995, рис. 11,5]; 7 - Лебедевка VII, кург. 17

[Железчиков и др., 2006, рис. 74,9]; 8 - Филипповка I, кург. 12 [Пшеничнюк, 2012, рис. 118,10]; 9-10 - Филипповка I, кург. 1, околокурганное пространство [Яблонский, 2013, № 3126, 3127];

11-12 - Кырык-Оба II, кург. 16 [Гуцалов, 2011, рис. 5,3,4]; 13-21 - Пятимары II, кург. 5 [Смирнов, 1961, рис. 54]

Fig. 3. Bronze bridle plaques:

1 - Obruchevskiy, barrow 2 [Gavrilyuk, Tairov, 1993, fig. 5,4]; 2 - Bolshoy Klimovskiy [Tairov, 2000, fig. 43,2]; 3, 5 - Perevolochan I, barrow 10 [Pshenichnyuk, 1995, fig. 11,3; Mamedov, Kitov, 2015, fig. 11,4]; 4, 6 - Sapibulak, barrow 6, burial 4 [Mamedov, Kitov, 2015, fig. 11,3; Pshenichnyuk, 1995, fig. 11,5]; 7 - Lebedevka VII, barrow 17 [Zhelezchikov et al., 2006, fig. 74,9]; 8- Filippovka I, barrow 12 [Pshenichnyuk, 2012, fig. 118,10]; 9-10 - Filippovka I, near barrow 1 [Yablonsky, 2013, no. 3126, 3127];

11-12 - Kyryk-Oba II, barrow 16 [Gutsalov, 2011, fig. 5,3,4]; 13-21 - Pyatimary II, barrow 5 [Smirnov, 1961, fig. 54] 


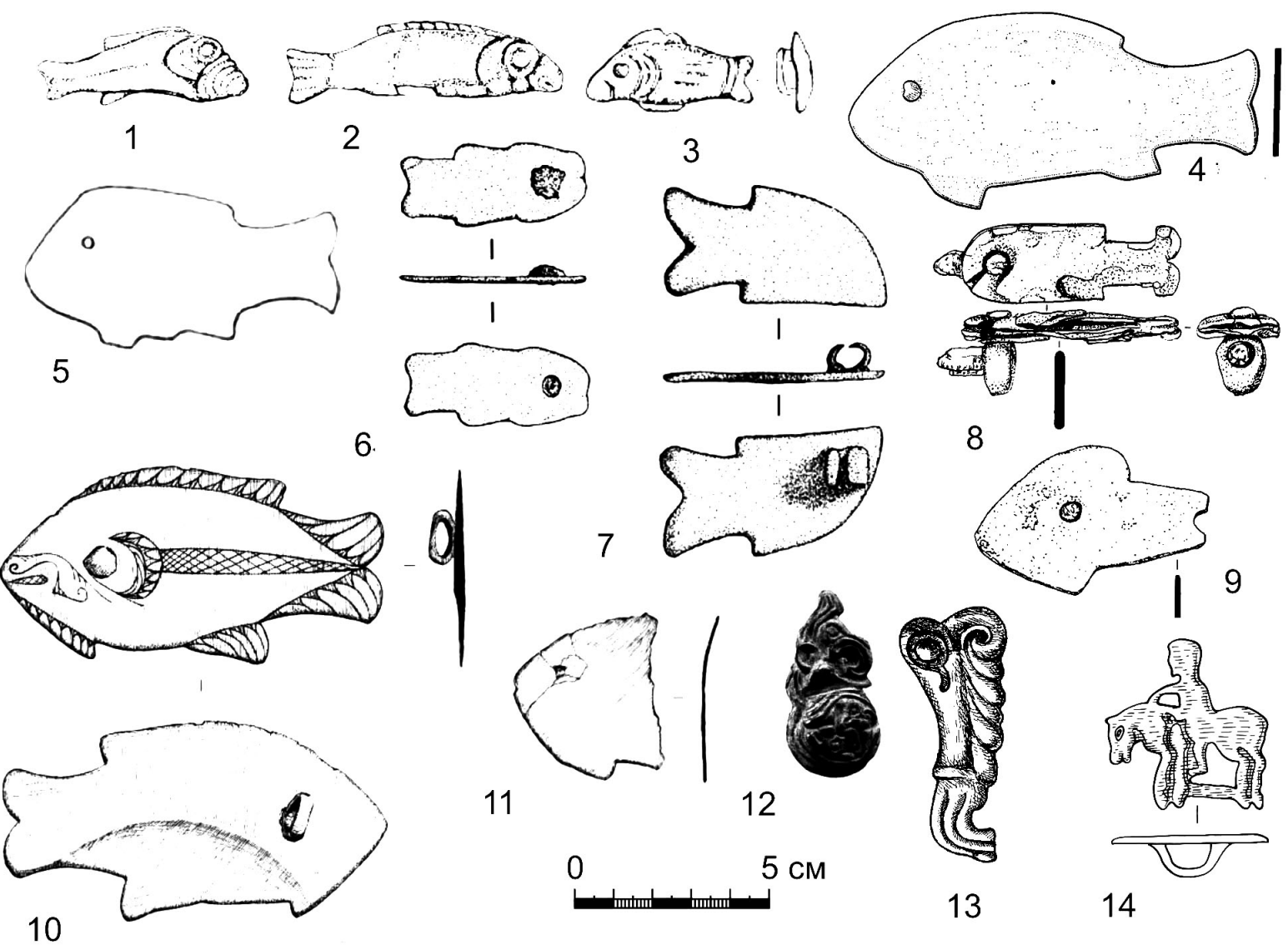

Рис. 4. Бронзовые уздечные бляшки:

1-2 - Нагорненский, кург. 6, погр. 1, кург. 9, погр. 8 [Королькова, 2006, табл. 1,3,6]; 3 - Уркач I, кург. 23 [Королькова, 2006, табл. 1,7]; 4-5 - Ак-Булак [Смирнов, 1961, рис. 38,12]; 6-7 - Переволочан I, кург. 11, погр. 1

[Сиротин, 2010, рис. 3,14]; 8-9 - Акоба II, кург. 1, погр. 2 [Моргунова, Краева, 2013, рис. 17,5,6];

10-11 - Сара, кург. 4, погр. 1 [Федоров, Васильев, 2017, рис. 3,4,7]; 12 - Филипповка I, кург. 1, околокурганное пространство [Яблонский, 2013, № 3125]; 13 - Филипповка I, кург. 3 [Пшеничнюк, 2012, рис. 57,15]; 14 - Переволочан I, кург. 10 [Пшеничнюк, 1995, рис. 11,13]

Примечание. Масштаб указан для 4-14.

Fig. 4. Bronze bridle plaques:

1-2 - Nagornenskiy, barrow 6, burial 1, barrow 9, burial 8 [Korolkova, 2006, table 1,3,6]; 3 - Urkach I, barrow 23 [Korolkova, 2006, table 1,7]; 4-5 - Ak-Bulak [Smirnov, 1961, fig. 38,12]; 6-7 - Perevolochan I, barrow 11, burial 1 [Sirotin, 2010, fig. 3,14]; 8-9-Akoba II, barrow 1, burial 2 [Morgunova, Kraeva, 2013, fig. 17,5,6]; 10-11 - Sara, barrow 4, burial 1 [Fedorov, Vasilyev, 2017, fig. 3,4,7]; 12 - Filippovka I, near barrow 1 [Yablonsky, 2013, no. 3125]; 13 - Filippovka I, barrow 3 [Pshenichnyuk, 2012, fig. 57,15]; 14 - Perevolochan I, barrow 10 [Pshenichnyuk, 1995, fig. 11,13]

Note. The size is specified for 4-14. 


\section{СПИСОК ЛИТЕРАТУРЫ}

Берлизов Н. Е., 2011. Ритмы Сарматии. Савроматосарматские племена Южной России в VII в. до н.э. - V в. н.э. Ч. І. Краснодар : КГУКИ ; Парабеллум. 320 c.

Гаврилюк А. Г., Таиров А. Д., 1993. Курганы у села Обручевка в Южном Зауралье // Кочевники урало-казахстанских степей. Екатеринбург : УИФ Наука. С. 53-71.

Грязнов М. П., 1956. Северный Казахстан в эпоху ранних кочевников // Краткие сообщения института истории материальной культуры. Вып. 61. С. 8-16.

Гуцалов С. Ю., 2010. Погребение сооружения могильника Кырык-Оба в Западном Казахстане // Российская археология. № 2. С. 51-66.

Гуцалов С. Ю., 2011. Этнокультурная специфика могильника Кырык-Оба II // Российская археология. № 1. С. 81-96.

Дворниченко В. В., Очир-Горяева М. А., 1997. Хошеутовский комплекс уздечных принадлежностей скифского времени на Нижней Волге // Донские древности. Сарматы и Скифия : сб. науч. докл. III Междунар. конф. «Проблемы сарматской археологии и истории». Вып. 5. Азов : Книга. С. 99-115.

Железчиков Б. Ф., Клепиков В. М., Сергацков И. В., 2006. Древности Лебедевки (VI-II вв. до н.э.). М. : Восточная литература. 159 с.

Кадырбаев М. К., 1984. Курганные некрополи верховьев р. Илек // Древности Евразии в скифосарматское время. М. : Наука. С. 84-107.

Кантарович А. Р., Яблонский Л. Т., 2009. О северопричерноморских и северокавказских параллелях изображениям в скифо-сибирском зверином стиле на предметах из Филипповских курганов // Нижневолжский археологический вестник. Вып. 10. С. 73-99.

Королькова Е. Ф., 2006. Звериный стиль Евразии. Искусство племен Нижнего Поволжья и Южного Приуралья в скифскую эпоху (VII IV вв. до н.э.). Проблемы стиля и интерпретации. СПб. : Петербургское Востоковедение. $272 \mathrm{c}$.

Кузнецова Э. Ф., Курманкулов Ж. К., 1993. Бронзовые изделия из памятников савроматской культуры Западного Казахстана (данные спектрального анализа) // Кочевники урало-казахстанских степей. Екатеринбург : УИФ Наука. C. 44-52.

Мамедов А. М., Китов Е. П., 2015. Погребальный обряд ранних кочевников верхнего Илека по материалам могильника Сапибулак // Известия Национальной академии наук Республики Казахстан. № 6 (304). С. 19-60.
Моргунова Н. Л., Краева Л. А., 2012. Курганная группа Акоба II // Археологические памятники Оренбуржья. Вып. 10. Оренбург : Изд-во ОГПУ. С. 156-199.

Мошкова М. Г., 1972. Савроматские памятники северо-восточного Оренбуржья // Памятники Южного Приуралья и Западной Сибири сарматского времени. Материалы и исследования по археологии СССР. № 153. М. : Наука. C. $49-78$.

Мышкин В. Н., 2014. К проблеме типологии одной группы уздечных бляшек у кочевников Южного Урала в скифское время // Известия Самарского научного центра Российской академии наук. Т. 16. № 3 (2). С. 605-610.

Мышкин В. Н., 2015. О некоторых категориях украшений наносных и налобных ремней конской узды у кочевников Южного Урала в скифское время // Известия Самарского научного центра Российской академии наук. Т. 17. № 3. C. $273-280$.

Мышкин В. Н., 2018а. Конские налобники из кочевнических курганов скифского времени на Южном Урале // Нижневолжский археологический вестник. T. 17. Вып. 2. С. 5-17. DOI: https://doi.org/10.15688/nav.jvolsu.2018.2.1.

Мышкин В. Н., 2018б. Курган 21 могильника Филипповка I: предметы конского снаряжения и дата комплекса // Самарский научный вестник. Т. 7. № 3 (24). С. 283-287.

Очир-Горяева М. А., 2012. Древние всадники степей Евразии. М. : Таус. 472 c.

Пшеничнюк А. Х., 1995. Переволочанский могильник // Курганы кочевников Южного Урала. Уфа: Гилем. С. 62-96.

Пшеничнюк А. Х., 2012. Филипповка: Некрополь кочевой знати IV века до н.э. на Южном Урале. Уфа : ИИЯЛ УНЦ РАН. 280 с.

Сиротин С. В., 2010. Курган № 11 курганного могильника Переволочан в Зауральской Башкирии // Археология и палеоантропология Евразийских степей и сопредельных территорий. М. : Таус. С. 323-338.

Сиротин С. В., 2015а. Предметы конской сбруи из насыпей курганов ранних кочевников Южного Урала (по материалам раскопок 2008-2013 годов) // Этнические взаимодействия на Южном Урале : материалы VI Всерос. науч. конф. Челябинск : Челяб. гос. краевед. музей. С. 247-255.

Сиротин С. В., 2015б. Охранные исследования на могильнике «Ивановские I курганы» в 20132014 годах // Известия Археологического общества Республики Башкортостан. Вып. 1 (2). C. 18-19.

Сиротин С. В., 2016. Об относительной хронологии и датировке могильника Переволочан I // Кон- 
стантин Федорович Смирнов и современные проблемы сарматской археологии : материалы IX Междунар. науч. конф. «Проблемы сарматской археологии и истории», посвященной 100-летию со дня рождения Константина Федоровича. Оренбург : Изд-во ОГПУ. С. 253-264.

Смирнов К. Ф., 1961. Вооружение савроматов // Материалы и исследования по археологии СССР. № 101. М. : АН СССР. 168 c.

Смирнов К. Ф., 1964. Савроматы. Ранняя история и культура сарматов. М. : Наука. 380 с.

Таиров А. Д., 2000. Ранний железный век // Древняя история Южного Зауралья. Челябинск : Изд-во ЮУрГУ. С. 3-205.

Таиров А. Д., 2004. Периодизация памятников ранних кочевников Южного Зауралья VII-II вв. до н.э. // Сарматские культуры Евразии: проблемы региональной хронологии : докл. к V Междунар. конф. «Проблемы сарматской археологии и истории». Краснодар : [б. и.]. С. 3-21.

Трейстер М. Т., Яблонский Л. Т., 2012. К вопросу об абсолютной дате могильника Филипповка-I // Влияния ахеменидской культуры в Южном Приуралье (V-III вв. до н.э.). Т. І. М. : Tayc. C. 282-284.

Трейстер М. Т., Шемаханская М. С., Яблонский Л. Т., 2012. Комплексы с предметами ахеменидского круга могильника Филипповка-I // Влияния ахеменидской культуры в Южном Приуралье (VIII вв. до н.э.). Т. II. М. : Таус. С. 85-156.

Федоров В. К., 2015. Уздечные наборы с бляхами в виде рыб из погребений ранних кочевников Южного Урала // Этнические взаимодействия на Южном Урале : материалы VI Всерос. науч. конф. Челябинск : [б. и.]. С. 256-260.

Федоров В. К., Васильев В. Н., 2017. Уздечный набор с бляхами в виде рыб из кургана № 4 могильника Сара в Восточном Оренбуржье // Вестник Южно-уральского государственного университета. Серия «Социально-гуманитарные науки». Т. 17. № 1. С. 54-62.

Яблонский Л. Т., 2008а. Новые раскопки Филипповского I курганного могильника // Археология Восточно-европейской степи : межвуз. сб. науч. тр. Вып. 6. Саратов : Научная книга. С. 253-268.

Яблонский Л. Т., 2008б. Новые раскопки Флипповского могильника и проблема формирования раннесарматской культуры Южного Приуралья // Ранние кочевники Волго-Уральского региона : материалы междунар. науч. конф. «Ранние кочевники Южного Приуралья в свете новейших археологических открытий». Оренбург, 21-25 апреля 2008 г. Оренбург : Изд-во ОГПУ. С. 170-176.

Яблонский Л. Т., 2013. Золото сарматских вождей. Элитный некрополь Филипповка I (по мате- риалам раскопок 2004-2009 гг.). Каталог коллекции. Книга 1. М. : ИА РАН. 232 с.

\section{REFERENCES}

Berlizov N.E., 2011. Rhythms of Sarmatia. The Sauromatic-Sarmatian tribes of Southern Russia in the VII century BC - V century AD, p. I. Krasnodar, KGUKI, Parabellum Publ., 320 p. (in Russian).

Gavrilyuk A.G., Tairov A.D., 1993. Kurgans near the Village Obruchevka in the Southern Urals. Kochevniki uralo-kazakhstanskikh stepey. Ekaterinburg, UIF Nauka Publ., pp. 53-71. (in Russian).

Gryaznov M.P., 1956. Northern Kazakhstan in the Era of Early Nomads. Brief Communications of the Institute of History of Material Culture, iss. 61, pp. 8-16. (in Russian).

Gutsalov S.Yu., 2010. Burial Structures of Kyryk-Oba II Cemetery in Western Kazakhstan. Rossiyskaya arkheologiya, no. 2, pp. 51-66. (in Russian).

Gutsalov S.Yu., 2011. The Ethnic and Cultural Specifics of Kyryk-Oba II Cemetery. Rossiyskaya arkheologiya, no. 1, pp. 81-96. (in Russian).

Dvornichenko V.V., Ochir-Goryaeva M.A., 1997. Hosheutov Complex of Bridle Accessories of the Scythian Time on the Lower Volga. Donskie drevnosti. Sarmaty i Skifiya : sb. nauch. dokl. III mezhdunar. konf. "Problemy sarmatskoy arkheologii i istorii”, iss. 5. Azov, Kniga, pp. 99115. (in Russian).

Zhelezchikov B.F., Klepikov V.M., Sergatskov I.V., 2006. Antiquities of Lebedevka (VI-II centuries BC). Moscow, Vostochnaya literatura Publ., 159 p. (in Russian).

Kadyrbaev M.K., 1984. Kurgan Necropolises of the Upper Reaches of Ilek. Drevnosti Evrazii v skifosarmatskoe vremya. Moscow, Nauka Publ., pp. 84-107. (in Russian).

Kantarovich A.R., Yablonsky L.T., 2009. North-Pontic and North-Caucasian Analogies to the ScythoSiberian Style Images Decorating the Objects from the Filippovka Barrows. The Lower Volga Archaeological Bulletin, iss. 10, pp. 73-99. (in Russian).

Korolkova E.F., 2006. Animal Style of Eurasia. The Art of the Tribes of the Lower Volga Region and Southern Urals in the Scythian Period (VIIIV centuries BC). Problems of Style and Interpretation. Saint-Petersburg, Peterburgskoye Vostokovedeniye Publ. 272 p. (in Russian).

Kuznetsova E.F., Kurmankulov Zh.K., 1993. Bronze Products from the Monuments of Sauromatic Culture of Western Kazakhstan (Spectral 
Analysis Data). Kochevniki uralokazahstanskih stepey. Ekaterinburg, UIF Nauka Publ., pp. 44-52. (in Russian).

Mamedov A.M., Kitov E.P., 2015. Funeral Ceremony of Early Nomads from the Top Ilek (on the Materials of the Burial Ground Sapibulak). News of the National Academy of Sciences of the Republic of Kazakhstan, no. 6(304), pp. 19-60. (in Russian).

Morgunova N.L., Krayeva L.A., 2012. Kurgan Group Akoba II. Arkheologicheskiye pamyatniki Orenburzhia, iss. 10. Orenburg, OGPU, pp. 156199. (in Russian).

Moshkova M.G., 1972. Sauromatian Monuments of the Northeast of the Orenburg Region. Pamyatniki Yuzhnogo Priuralia i Zapadnoy Sibiri sarmatskogo vremeni, Materialy $i$ issledovaniya po arkheologii SSSR, no.153. Moscow, Nauka Publ., pp. 49-78. (in Russian).

Myshkin V.N., 2014. To the Problem of Typology of One Group of Bridle Horse Brass of the Nomads of South Ural in Scythian Time. News of the Samara Scientific Center of the Russian Academy of Sciences, vol. 16, no. 3 (2), pp. 5-17. (in Russian).

Myshkin V.N., 2015. On Some Kinds of Decorations of Nosebands and Brow Bands of Horse Bridle of the South Ural Nomads in the Scythian Times. News of the Samara Scientific Center of the Russian Academy of Sciences, vol. 17, no. 3, pp. 273-280. (in Russian).

Myshkin V.N., 2018a. Forehead Pieces from Nomadic Barrows of the Scythian Time in the Southern Urals. The Lower Volga Archaeological Bulletin, vol. 17, iss. 2, pp. 5-17. (in Russian). DOI: https:// doi.org/10.15688/nav.jvolsu.2018.2.1.

Myshkin V.N., 20186. Burial Mound 21 of the Burial Ground Filippovka I: Items of Horse Equipment and the Date of the Complex. Samara Journal of Science, vol. 7, no 3 (24), pp. 283-287. (in Russian).

Ochir-Goryaeva M.A., 2012. The Ancient Riders of the Steppes of Eurasia. Moscow, Taus Publ. 472 p. (in Russian).

Pshenichnyuk A.Kh., 1995. Perevolochan Burial Ground. Kurgany kochevnikov Yuzhnogo Urala. Ufa, Gilem Publ., pp. 62-96. (in Russian).

Pshenichnyuk A.Kh., 2012. Filippovka: Necropolis of the Nomadic Nobility of the $4^{\text {th }}$ Century $B C$ in the Southern Urals. Ufa, IHLL USC RAS. 280 p. (in Russian).

Sirotin S.V., 2010. Kurgan no. 11 of the Burial Mound of Perevolochan in the Trans-Ural Bashkiria. Arkheologiya i paleoantropologiya Evraziyskikh stepey i sopredel'nykh territoriy. Moscow, Taus Publ., pp. 323-338. (in Russian).

Sirotin S.V., 2015a. Items of Harness from Mounds of Barrows of the Early Nomads of the Southern Ural (on the Materials of Excavations 2008-2013). Etnicheskie vzaimodeystviya na Yuzhnom Urale: materialy VI Vseros. nauch. konf. Chelyabinsk, Chelyab. gos. krayeved. muzey, pp. 247-255. (in Russian).

Sirotin S.V., 20156. Rescue Excavations at the Kurgan Cemetery "Ivanovskye I Burial" in 2013-2014. Izvestiya Arheologicheskogo obshchestva Respubliki Bashkortostan, iss. 1 (2), pp. 18-19. (in Russian).

Sirotin S.V., 2016. On a Conventional Chronology and Dating of the Perevolochan I Burial. Konstantin Fedorovich Smirnov i sovremennye problemy sarmatskoy arkheologii. Materialy IX Mezhdunar. nauch. konf. "Problemy sarmatskoy arkheologii $i$ istorii". Orenburg, OSPU, pp. 253-264. (in Russian).

Smirnov K.F., 1961. Weapons of the Sauromatian. Materialy i issledovaniya po arkheologii SSSR, no. 101. Moscow, AS USSR. 168 p. (in Russian).

Smirnov K.F., 1964. Sauromatians: Early History and Culture of the Sarmatians. Moscow, Nauka Publ. 380 p. (in Russian).

Tairov A.D., 2000. Early Iron Age. Drevnyaya istoriya Yuzhnogo Zaural'ya. Chelyabinsk, SUSU, pp. 3205. (in Russian).

Tairov A.D., 2004. Periodization of Monuments of Early Nomads of the Southern Trans-Urals 7-2 Centuries BC. Sarmatskiye kul'tury Evrazii: problemy regional'noy khronologii : Dokl. $k$ V Mezhdunar. konf. "Problemy sarmatskoy arkheologii i istorii”. Krasnodar, [s. n.], pp. 321. (in Russian).

Treister M.Yu., Yablonsky L.T., 2012. On the Question of the Absolute Date of the Filippovka-I Burial Ground. Vliyaniya akhemenidskoy kul'tury $v$ Yuzhnom Priural'ye (V-III vv. do n.e.), vol. I. Moscow, Taus Publ., pp. 282-284. (in Russian).

Treister M.T., Shemakhanskaya M.S., Yablonsky L.T. (2012). Complexes with objects of the Achaemenid circle of the Filippovka-I burial ground. Vliyaniya akhemenidskoy kul'tury v Yuzhnom Priural'ye (V-III vv. do n.e.), vol. II. Moscow, Taus Publ., pp. 85-156. (in Russian).

Fedorov V.K., 2015. Bridle Sets with Plaques in the Form of Fish from the Burials of the Early Nomads of the Southern Urals. Ehtnicheskie Vzaimodeystviya na Yuzhnom Urale : materialy VI Vseros. nauch. konf. Chelyabinsk, [s. n.], pp. 256-260. (in Russian).

Fedorov V.K., Vasilyev V.N., 2017. Bridle Sets with Plaques in the Form of Fish from Sara Burial Mound № 4 in the Eastern Orenburg Region. Bulletin of the South Ural State University. Series "Social Sciences and the Humanities", vol. 17, no. 1, pp. 54-62. (in Russian). 
Yablonsky L.T., 2008a. New Excavations of the Filippovka I Burial Mound Arkheologiya Vostochno-yevropeyskoy stepi : mezhvuz. sb. nauch. tr., iss. 6. Saratov, Nauchnaya kniga Publ., pp. 253-268. (in Russian).

Yablonsky L.T., 20086. New Excavations of the Flippovsky Burial Ground and the Problem of the Formation of the Early Sarmatian Culture of the Southern Urals. Ranniye kochevniki Volgo-
Ural'skogo regiona: materialy mezhdunar. nauch. konf. "Ranniye kochevniki Yuzhnogo Priural'ya v svete noveyshikh arkheologicheskikh otkrytiy". Orenburg, 21-25 aprelya 2008 g., Orenburg, OSPU, pp. 170-176. (in Russian).

Yablonsky L.T., 2013. Gold Sarmatian Leaders. Elite Necropolis Filippovka I (According to the Excavations of 2004-2009). Katalog kollektsii, book 1. Moscow, IA RAS. 232 p. (in Russian).

\section{Information about the Author}

Vladimir N. Myshkin, Candidate of Sciences (History), Head of Archaeological Laboratory, Samara State University of Social Sciences and Education, Leninskaya St., 127, 443041 Samara, Russian Federation, vnm59@bk.ru, https://orcid.org/0000-0003-3489-6776

\section{Информация об авторе}

Владимир Николаевич Мышкин, кандидат исторических наук, заведующий археологической лабораторией, Самарский государственный социально-педагогический университет, ул. Ленинская, 127, 443041 г. Самара, Российская Федерация, vnm59@bk.ru, https://orcid.org/0000-0003-3489-6776 